\title{
Insulin-mediated and glucose-mediated glucose uptake following hemipancreatectomy in healthy human donors
}

\author{
E. R.Seaquist ${ }^{1}$, K. Pyzdrowski ${ }^{1}$, A.Moran ${ }^{2}$, A. U. Teuscher ${ }^{1}$, R.P. Robertson ${ }^{1}$ \\ ${ }^{1}$ Diabetes Center and the Division of Diabetes, Endocrinology, and Metabolism, Department of Medicine, University \\ of Minnesota Medical School, Minneapolis, Minnesota, USA \\ ${ }^{2}$ Department of Pediatrics, University of Minnesota Medical School, Minneapolis, Minnesota, USA
}

Summary Healthy humans undergoing hemipancreatectomy for the purpose of donation to a family member with IDDM have previously been demonstrated to maintain serum glucose values equal to matched control subjects during short-term glucose infusion despite significant decrements in glucose- and arginine-induced insulin secretion. In order to determine whether humans compensate for hemipancreatectomy by increasing insulin- or glucose-mediated glucose uptake, we measured glucose turnover and insulin sensitivity by three protocols. Insulin-mediated glucose uptake was measured during sequential infusions of insulin at rates of $0.25,1.0$, and $10.0 \mathrm{mU} \cdot \mathrm{kg}^{-1} \cdot \mathrm{min}^{-1}$ in 12 donor subjects and 12 matched control subjects maintained at euglycaemia. Both groups displayed similar increases in rates of glucose disappearance and similar decreases in rates of hepatic glucose production. Glucose-mediated uptake was calculated as the difference between the rates of glucose disappearance measured during a hyperglycaemic clamp and a euglycaemic clamp performed at identical rates of insulin infusion and was also found to be similar in both donor subjects and control subjects. Both groups also had indistinguishable measures of insulin sensitivity and glucose effectiveness as determined by the minimal model technique. Therefore, donor subjects appear to compensate for diminished insulin secretion following hemipancreatectomy by an unidentified mechanism since neither insulin- nor glucose-mediated glucose uptake are increased. [Diabetologia (1994) 37: 1036-1043]

Key words Insulin action, pancreatectomy, glucose uptake, pancreas transplantation, minimal model.
The metabolic effects of partial pancreatectomy have drawn much attention in recent years because of the insights this model provides in understanding the role of beta-cell mass in glucose homeostasis. While most investigation has been performed using animal models [1-6], observations made in hemipancreatectomized humans, especially in those who are healthy

Received: 17 January 1994

and in revised form: 10 May 1994

Corresponding author: Dr. E.R. Seaquist, The Diabetes Center, Box 101 UMHC, University of Minnesota, Minneapolis, MN 55455, USA

Abbreviations: $\mathrm{R}_{\mathrm{d}}$, Rate of glucose disappearance; HGP, hepatic glucose production rate; IDDM, insulin-dependent diabetes mellitus; $S_{I}$, insulin sensitivity index; $S_{G}$, glucose effectiveness. at the time of surgery and undergo the procedure for the purpose of organ donation to a family member with diabetes, are particularly applicable to the understanding of human physiology and disease. Hemipancreatectomy in humans for the purpose of organ donation causes abnormal glucose tolerance in $25 \%$ of subjects examined 1 year after surgery [7]. Daily glucose profiles were normal in 17 donor subjects studied by Kendall et al. [7] 1 year after donation and dónor subjects have been reported to maintain normal fasting glucose concentrations for many years after hemipancreatectomy $[7,8]$. However, significant defects in pancreatic beta- and alpha-cell function have been observed even in healthy hemipancreatectomized human donor subjects with normal glucose tolerance. We have previously reported that these subjects experience an approximately $50 \%$ reduction in glucose- and arginine-induced insu- 
lin secretion, glucose potentiation of arginine-induced insulin secretion, and arginine-induced glucagon-secretion following hemipancreatectomy [8]. Surprisingly, despite these striking abnormalities in islet secretion, hemipancreatectomized human donor subjects maintain glucose values identical to control subjects during short-term glucose infusion [8]. These observations led us to propose that donor subjects might maintain normal glucose homeostasis following hemipancreatectomy through a compensatory increase in their rates of glucose disposal.

In the fasting state, glucose disposal occurs largely through glucose-mediated mechanisms [9]. Postprandially, or following insulin infusions, insulin-mediated glucose uptake becomes the dominant process through which glucose enters cells. Alterations in either glucose-mediated or insulin-mediated glucose uptake could allow healthy donor subjects to maintain normal glucose homeostasis despite diminished insulin secretory capacity following a reduction in their beta-cell mass. Consequently, we measured both glucose-mediated and insulin-mediated glucose uptake in hemipancreatectomized healthy human donor subjects characterized by non-diabetic glucose tolerance tests and diminished insulin secretion. In our study we used a 2-day hyperinsulinaemic clamp protocol with euglycaemia maintained on day 1 and hyperglycaemia with a concurrent somatostatin infusion maintained on day 2. Insulin-mediated glucose uptake was measured during the first day of the protocol and compared with the glucose disposal rates measured on the second day which allowed for a calculation of glucose-mediated glucose uptake. These measures of glucose turnover were then compared to measures of insulin sensitivity $\left(\mathrm{S}_{\mathrm{I}}\right)$ and glucose effectiveness $\left(S_{G}\right)$ determined by the minimal model technique.

\section{Subjects and methods}

Patient selection. Hemipancreatectomized subjects were recruited from patients at the University of Minnesota who had served as pancreas donor subjects for family members with IDDM. As of 1 January 1993, 77 individuals have undergone this procedure, the details of which are included in a previous publication [7]. Healthy control subjects were selected to match the donor subjects with respect to age, sex, and body mass index. These studies were approved by the Committee on the Use of Human Subjects in Research at the University of Minnesota and all the participants provided written consent.

Glucose tolerance and insulin secretion studies. Glucose tolerance was assessed through measurement of serum glucose concentrations obtained following ingestion of $1.75 \mathrm{~g}$ glucose $\cdot \mathrm{kg}$ body weight ${ }^{-1}$, as previously described [7]. Insulin secretion was measured as serial serum insulin values obtained at $-5,0$, $2,3,4$, and $5 \mathrm{~min}$ after the administration of $20 \mathrm{~g}$ of glucose as an intravenous bolus [8].

Hyperinsulinaemic clamp studies. All testing was performed at the General Clinical Research Center at the University of
Minnesota following a $10-12 \mathrm{~h}$ overnight fast. Three intravenous catheters were placed in each subject more than $120 \mathrm{~min}$ before the first sample was drawn. One catheter was placed in an antecubital vein for the infusion of glucose (as $50 \%$ dextrose) and insulin. A contralateral hand vein was cannulated retrogradely and served as the source for blood samples. In order to arterialize the venous blood, the hand bearing the catheter for blood sampling was placed in a warming chamber set at $55-60^{\circ} \mathrm{C} 30 \mathrm{~min}$ before the first sample was obtained and held there for the duration of the study. A forearm vein proximal to the hand vein was cannulated for the continuous infusion of trace amounts of $\left[3{ }^{3} \mathrm{H}\right]$-glucose (NEN-Dupont, North Billerica, Mass., USA) and potassium phosphate. Subjects were instructed to remain supine for the duration of the study. The hyperinsulinaemic euglycaemic clamp (day 1 ) was performed at least 1 day and not more than 5 days before the hyperinsulinaemic hyperglycaemic clamp study (day 2).

On the first day of study, subjects were given a bolus of [3$\left.{ }^{3} \mathrm{H}\right]$-glucose $(6 \mu \mathrm{Ci})$ at $-120 \mathrm{~min}$ followed by continuous infusion at a rate of $6 \mu \mathrm{Ci} / \mathrm{h}$ for the duration of the test. The insulin infusion (Humulin, Eli Lilly, Indianapolis, Ind., USA) was begun at time 0 and three sequential infusion rates of insulin were administered: $0.25 \mathrm{mU} \cdot \mathrm{kg}^{-1} \cdot \mathrm{min}^{-1}$ for $180 \mathrm{~min}$, then $1.0 \mathrm{mU} \cdot \mathrm{kg}^{-1} \cdot \mathrm{min}^{-1}$ for $120 \mathrm{~min}$, and then $10.0 \mathrm{mU} \cdot \mathrm{kg}^{-1}$. $\mathrm{min}^{-1}$ for the final $120 \mathrm{~min}$. Euglycaemia was maintained at $5.3 \mathrm{mmol} / \mathrm{l}$ by a variable infusion of $50 \%$ dextrose that was adjusted according to plasma glucose determinations made at 5min intervals. The dextrose used to maintain euglycaemia was radiolabelled with $\left[3-{ }^{3} \mathrm{H}\right]$-glucose to bring it to the same specific activity as the subject's plasma at the end of the $120-\mathrm{min}$ isotopic equilibration period. The specific activity (SA) of the subject's plasma was estimated by the equation:

$$
\begin{aligned}
& \mathrm{SA}=\frac{\mathrm{F}}{(\text { Basal rate endogenous glucose production })(\mathrm{kg} \text { body weight })} \\
& \text { where: } \mathrm{SA}=\mathrm{dpm} / \mathrm{mg} \text { glucose } \\
& \\
& \quad \mathrm{F}=\text { flow rate of isotopic tracer } \\
& \quad \text { Basal rate of endogenous glucose production } \\
& \quad \sim 2 \mathrm{mg} \cdot \mathrm{kg}^{-1} \cdot \mathrm{min}^{-1}
\end{aligned}
$$

Infusions of insulin and $\left[3{ }^{3} \mathrm{H}\right]$-glucose were delivered by Harvard pumps (Model 22 Multi, Harvard Apparatus, South Natick, Mass., USA). Blood samples were obtained every 20 min for later determination of insulin and specific activity.

On the second day of study, a clamp procedure was performed as on day 1 except that somatostatin was administered throughout the experimental period. The goal infusion rate of somatostatin was $0.16 \mu \mathrm{g} \cdot \mathrm{kg}^{-1} \cdot \mathrm{min}^{-1}$ and subjects were brought up to this rate within 60 min depending on their tolerance to the drug. The somatostatin infusion was well tolerated by both the donor and the control subjects. On day 2 two sequential insulin infusion rates were administered: $0.25 \mathrm{mU} \cdot \mathrm{kg}^{-1} \cdot \mathrm{min}^{-1}$ for $180 \mathrm{~min}$ followed by $1.0 \mathrm{mU} \cdot \mathrm{kg}^{-1}$. $\min ^{-1}$ for $120 \mathrm{~min}$. Hyperglycaemia was maintained at $11.1 \mathrm{mmol} / \mathrm{l}$ throughout the study day. Urine was collected during the experimental period for later determination of glucose excretion during hyperglycaemia.

Minimal model evaluation. Some subjects were also evaluated using the minimal model technique [10]. For these examinations, subjects were studied in the morning after an overnight fast. Intravenous catheters were placed in each arm and the arm containing the sampling catheter was placed in a warming chamber set at $55-60^{\circ} \mathrm{C} 30 \mathrm{~min}$ before the first sample was drawn. Four baseline samples for glucose and insulin were obtained before glucose was administered intravenously at a dose of $300 \mathrm{mg} \cdot \mathrm{kg}^{-1}$ (given as $50 \%$ dextrose) over $1 \mathrm{~min}$ at 
Table 1. Subject characteristics

\begin{tabular}{|c|c|c|c|c|c|}
\hline & $\begin{array}{l}\text { Sex } \\
\text { (Male/Female) }\end{array}$ & $\begin{array}{l}\text { Age } \\
\text { (years) }\end{array}$ & $\begin{array}{l}\text { Body mass } \\
\text { index } \\
\left(\mathrm{kg} / \mathrm{m}^{2}\right)\end{array}$ & $\begin{array}{l}\text { Fasting } \\
\text { glucose } \\
(\mathrm{mmol} / 1)\end{array}$ & $\begin{array}{l}\text { Months } \\
\text { since pancreas } \\
\text { donation }\end{array}$ \\
\hline \multicolumn{6}{|c|}{ Hyperinsulinaemic clamp protocol } \\
\hline Control subjects & $0 / 12$ & $38 \pm 4$ & $24.0 \pm 1.0$ & $5.1 \pm 0.01$ & - \\
\hline Donor subjects & $0 / 12$ & $40 \pm 3$ & $24.9 \pm 1.1$ & $5.5 \pm 0.15$ & $75 \pm 13$ \\
\hline \multicolumn{6}{|c|}{ Minimal model protocol } \\
\hline Control subjects & $2 / 3$ & $45 \pm 5$ & $26.4 \pm 1.3$ & $5.4 \pm 0.2$ & - \\
\hline Donor subjects & $2 / 3$ & $45 \pm 4$ & $26.4 \pm 1.4$ & $5.5 \pm 0.3$ & $117 \pm 14$ \\
\hline
\end{tabular}

Table 2. Glucose tolerance and islet hormones in hemipancreatectomized donor subjects

\begin{tabular}{|c|c|c|c|c|c|c|c|c|}
\hline \multirow[b]{2}{*}{ Subject } & \multicolumn{5}{|c|}{ Oral glucose tolerance test Glucose (mmol/l) } & \multirow[b]{2}{*}{$\begin{array}{l}\text { Fasting } \\
\text { insulin } \\
(\mathrm{pmol} / \mathrm{l}) \\
\end{array}$} & \multirow[b]{2}{*}{$\begin{array}{l}\text { Fasting } \\
\text { glucagon } \\
\text { (ng/l) }\end{array}$} & \multirow[b]{2}{*}{$\begin{array}{l}\text { Acute insulin } \\
\text { response to intra } \\
\text { venous glucose (pmol/l) }\end{array}$} \\
\hline & $\begin{array}{l}\operatorname{Min} \\
-5\end{array}$ & 30 & 60 & 90 & 120 & & & \\
\hline 1 & 5.7 & 9.5 & 6.4 & 6.6 & 6.8 & 30 & 53 & 114 \\
\hline 2 & 6.4 & 10.2 & 10.3 & 10.0 & 10.8 & 72 & 83 & 54 \\
\hline 3 & 5.4 & 10.5 & 7.8 & 7.7 & 7.4 & 84 & 75 & 378 \\
\hline 4 & 5.8 & 9.7 & 9.0 & 8.4 & 8.4 & 42 & 125 & 90 \\
\hline 5 & 5.0 & & 4.3 & 8.0 & 8.2 & 36 & 90 & 312 \\
\hline 6 & 5.7 & 6.9 & 9.7 & 9.4 & 9.2 & 90 & & \\
\hline 7 & 5.7 & 9.8 & 11.1 & 11.9 & 8.3 & 36 & 53 & 42 \\
\hline 8 & 4.7 & 10.4 & 9.1 & 8.8 & 7.0 & 43 & & \\
\hline 9 & 5.4 & 10.9 & 11.8 & 10.3 & 9.2 & 54 & 109 & 234 \\
\hline 10 & 5.4 & 7.7 & 9.2 & 8.7 & 6.7 & 30 & 132 & 180 \\
\hline 11 & 6.2 & 7.6 & 12.1 & 13.1 & 9.8 & 36 & & 114 \\
\hline 12 & 5.7 & 11.1 & 13.3 & $11: 3$ & 10.8 & 54 & & 102 \\
\hline Mean & 5.6 & 9.5 & 9.5 & 9.5 & 8.6 & 51 & 90 & 162 \\
\hline SEM & 0.1 & 0.4 & 0.7 & 0.5 & 0.4 & 6 & 11 & 36 \\
\hline
\end{tabular}

time 0. Samples for glucose and insulin were then obtained at $\min 2,3,4,5,6,8,10,12,14,16$, and 19 . At $\min 20$ tolbutamide was administered intravenously over $30 \mathrm{~s}$. Subjects with a body mass index less than $30 \mathrm{~kg} / \mathrm{m}^{2}$ were given $300 \mathrm{mg}$ of tolbutamide whereas subjects with a body mass index greater that $30 \mathrm{~kg} / \mathrm{m}^{2}$ were given $500 \mathrm{mg}$ tolbutamide. Additional samples for glucose and insulin were then drawn at min $22,24,25,27$, $30,40,60,70,90,100,120,140,160$, and 180 .

Assays. Plasma glucose values were measured immediately using a Beckman Glucose Analyser (Fullerton, Calif., USA). Other measurements were made using frozen serum that had been separated from whole blood within $30 \mathrm{~min}$ after the sample was obtained. Serum insulin was determined by radioimmunoassay using a double antibody method [11]. Samples for glucagon were collected into pre-chilled tubes containing $2.5 \mathrm{mg}$ EDTA and $500 \mathrm{U}$ Trasylol (Miles, Inc., FBA Pharmaceuticals, West Haven, Conn., USA) per milliliter and centrifuged immediately. Glucagon was measured by radioimmunoassay [12] with antibody 04A obtained from Dr. R.H. Unger (University of Texas, Dallas, Tx., USA). Serum specific activity was determined after deproteinization [13, 14].

\section{Data analysis}

Data are presented as the mean and SEM. The acute insulin response to glucose was calculated as the mean of the peak three values minus the basal insulin concentration. Glucose turnover rates were calculated using the equations of Steele [15], as modified by DeBodo [16]. Glucose-mediated glucose uptake was determined as the difference in the rate of glucose disappearance measured between the euglycaemic (day 1) and hyperglycaemic (day 2) clamp studies during the final $40 \mathrm{~min}$ of the period during which insulin was infused at $1.0 \mathrm{mU} \cdot \mathrm{kg}^{-1}$. $\min ^{-1}$. Correction for urinary glucose excretion on day 2 was unnecessary since no glucose was detected in the urine of subjects during this protocol. Insulin sensitivity and glucose effectiveness were calculated using the MINMOD program (copyright R.N.Bergman, 1986) from the data obtained using the minimal model protocol. Differences between groups were determined using non-parametric analysis or ANOVA where appropriate. A $p$ value of $<0.05$ was considered statistically significant.

\section{Results}

Subject characteristics. Twelve human donor subjects were studied using the hyperinsulinaemic clamp protocol $75 \pm 13$ months following hemipancreatectomy (Table 1). All had non-diabetic responses (eight normal, four impaired, according to National Diabetes Data Group criteria) to the ingestion of $1.75 \mathrm{~g}$ glucose $\cdot \mathrm{kg}$ ideal body weight ${ }^{-1}$ and diminished acute insulin responses to glucose (Table 2). On average, the donor subjects were within $5 \mathrm{~kg}$ of their pre-operative weight and all were eating a normal diet. Twelve healthy control subjects were selected to match the 


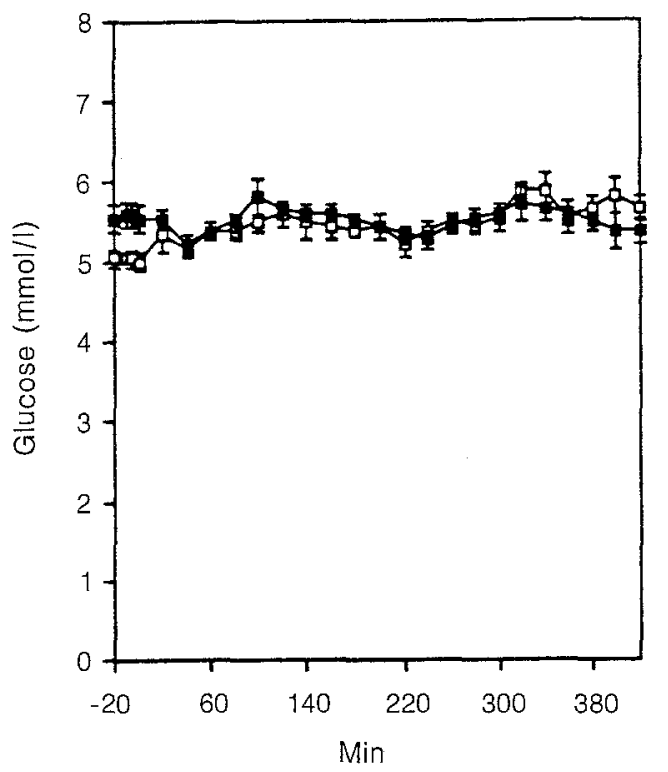

Fig. 1. Glucose and insulin values during hyperinsulinaemic euglycaemic clamp. Twelve donor subjects ( $\mathbf{a})$ and 12 control subjects $(\square)$ were clamped at approximately $5.3 \mathrm{mmol} / 1 \mathrm{glu}-$ cose (left panel) for $420 \mathrm{~min}$. Insulin was infused at a rate of $0.25 \mathrm{mU} \cdot \mathrm{kg}^{-1} \cdot \mathrm{min}^{-1}$ from $\min 0-180$, a rate of $1.0 \mathrm{mU} \cdot \mathrm{kg}^{-1}$. $\mathrm{min}^{-1}$ from $\min 180-300$, and a rate of $10.0 \mathrm{mU} \cdot \mathrm{kg}^{-1} \cdot \mathrm{min}^{-1}$ from $\min 300-420$. No differences were observed in the glucose and insulin values in donor and control subjects during the entire clamp study

donor subjects with respect to sex, age, and body mass index (Table 1). The fasting glucose values in the donor group were normal, but significantly higher than in the control subjects $(5.5 \pm 0.15$ vs $5.1 \pm 0.01 \mathrm{mmol} / 1$, donor subjects vs control subjects, $p=0.005$ ). Five donor subjects were studied using the minimal model protocol. They were studied $117 \pm 14$ months following donation and were matched to five healthy control subjects (Table 1). Fasting glucose values in this group of five donor subjects were also normal and were not different from control subjects $(5.5 \pm 0.3$ vs $5.4 \pm 0.2 \mathrm{mmol} / \mathrm{l})$.

Hyperinsulinaemic euglycaemic clamp. Both donor subjects and control subjects were clamped at a euglycaemic level during the sequential infusions of insulin on day 1 (Fig. 1). The serum specific activities achieved during this investigation are shown in Table 3 . In response to hyperinsulinaemia, each group demonstrated an increase in the rate of glucose disappearance $\left(\mathrm{R}_{\mathrm{d}}\right.$, Fig. 2$)$ to a maximum value of $14.92 \mathrm{mg} \cdot \mathrm{kg}^{-1} \cdot \mathrm{min}^{-1}$ in the donor subjects and $15.17 \mathrm{mg} \cdot \mathrm{kg}^{-1} \cdot \mathrm{min}^{-1}$ in the control subjects during the final $40 \mathrm{~min}$ during which insulin was infused at a rate of $10.0 \mathrm{mU} \cdot \mathrm{kg}^{-1} \cdot \mathrm{min}^{-1}$. No differences were found in the $R_{d}$ values measured in donor subjects and control subjects.

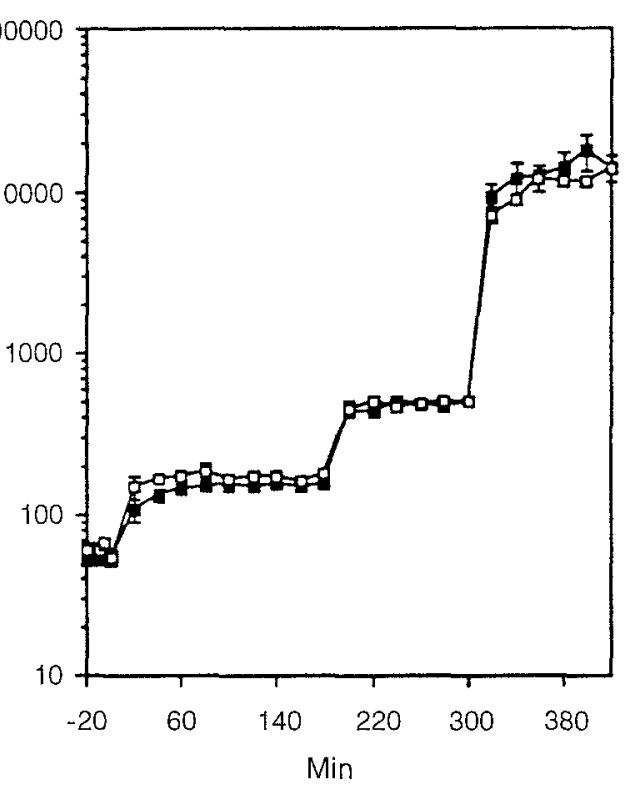

Table 3. Specific activity

\begin{tabular}{|c|c|c|c|c|c|}
\hline \multirow{2}{*}{$\begin{array}{l}\text { Protocol } \\
\text { day }\end{array}$} & \multirow{2}{*}{$\begin{array}{l}\text { Time } \\
(\mathrm{min})\end{array}$} & \multicolumn{2}{|c|}{ Donor subjects } & \multicolumn{2}{|c|}{ Control subjects } \\
\hline & & \multicolumn{2}{|c|}{ Mean \pm SEM } & \multicolumn{2}{|c|}{ Mean \pm SEM } \\
\hline \multirow[t]{24}{*}{1} & -10 & 1315 & 99 & 1041 & 200 \\
\hline & -5 & 1283 & 103 & 1020 & 195 \\
\hline & 0 & 1292 & 86 & 1016 & 189 \\
\hline & 20 & 1368 & 75 & 1057 & 194 \\
\hline & 40 & 1486 & 72 & 1127 & 205 \\
\hline & 60 & 1579 & 74 & 1198 & 216 \\
\hline & 80 & 1641 & 65 & 1263 & 229 \\
\hline & 100 & 1727 & 50 & 1306 & 240 \\
\hline & 120 & 1789 & 64 & 1322 & 242 \\
\hline & 140 & 1798 & 72 & 1320 & 239 \\
\hline & 160 & 1793 & 76 & 1329 & 241 \\
\hline & 180 & 1824 & 69 & 1381 & 252 \\
\hline & 200 & 1865 & 60 & 1415 & 260 \\
\hline & 220 & 1788 & 77 & 1344 & 246 \\
\hline & 240 & 1688 & 89 & 1288 & 238 \\
\hline & 260 & 1596 & 80 & 1209 & 224 \\
\hline & 280 & 1521 & 66 & 1121 & 207 \\
\hline & 300 & 1518 & 65 & 1114 & 205 \\
\hline & 320 & 1479 & 73 & 1072 & 199 \\
\hline & 340 & 1445 & 70 & 1046 & 193 \\
\hline & 360 & 1404 & 69 & 1025 & 187 \\
\hline & 380 & 1378 & 69 & 1005 & 185 \\
\hline & 400 & 1413 & 79 & 1022 & 185 \\
\hline & 420 & 1391 & 78 & 959 & 195 \\
\hline \multirow[t]{18}{*}{2} & -10 & 1164 & 51 & 769 & 208 \\
\hline & -5 & 1208 & 61 & 792 & 214 \\
\hline & 0 & 1253 & 90 & 818 & 215 \\
\hline & 20 & 1325 & 87 & 843 & 219 \\
\hline & 40 & 1385 & 57 & 875 & 236 \\
\hline & 60 & 1407 & 65 & 882 & 237 \\
\hline & 80 & 1409 & 69 & 907 & 244 \\
\hline & 100 & 1496 & 54 & 974 & 266 \\
\hline & 120 & 1502 & 60 & 970 & 264 \\
\hline & 140 & 1498 & 65 & 977 & 265 \\
\hline & 160 & 1545 & 55 & 1014 & 279 \\
\hline & 180 & 1584 & 69 & 1039 & 282 \\
\hline & 200 & 1581 & 65 & 1029 & 279 \\
\hline & 220 & 1569 & 58 & 998 & 273 \\
\hline & 240 & 1549 & 72 & 976 & 262 \\
\hline & 260 & 1510 & $7 \overline{2}$ & 948 & 253 \\
\hline & 280 & 1469 & 65 & 915 & 246 \\
\hline & 300 & 1443 & 67 & 895 & 240 \\
\hline
\end{tabular}




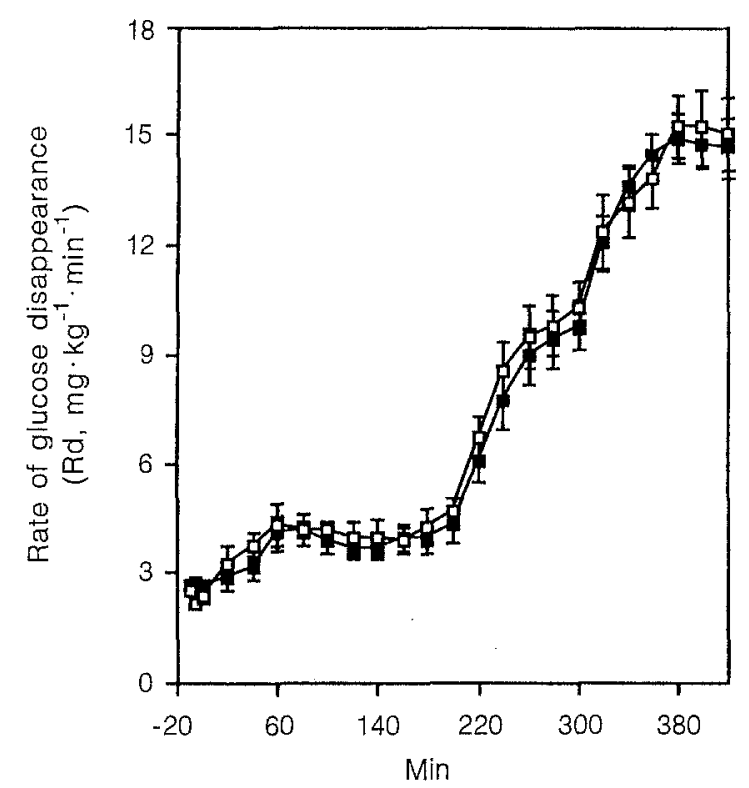

Fig. 2. Glucose turnover rates during hyperinsulinaemic euglycaemic clamp. Twelve donor subjects ( $\mathbf{m}$ ) and 12 control subjects $(\square)$ were clamped at approximately $5.3 \mathrm{mmol} / 1$ glucose for $420 \mathrm{~min}$. Insulin was infused at rate of $0.25 \mathrm{mU} \cdot \mathrm{kg}^{-1}$. $\mathrm{min}^{-1}$ from min $0-180$, a rate of $1.0 \mathrm{mU} \cdot \mathrm{kg}^{-1} \cdot \mathrm{min}^{-1}$ from min $180-300$, and a rate of $10.0 \mathrm{mU} \cdot \mathrm{kg}^{-1} \cdot \mathrm{min}^{-1}$ from min 300 420. During these stepped sequential infusions of insulin both donor subjects and control subjects displayed similar increases in their rates of glucose disappearance (left panel) and decreases in their rates of the hepatic glucose production (right panel)

Rates of HGP were noted to decrease in each group following start of the insulin infusion (Fig. 2). Donor subjects and control subjects demonstrated complete suppression of HGP by insulin administered at a rate of $1.0 \mathrm{mU} \cdot \mathrm{kg}^{-1} \cdot \mathrm{min}^{-1}$. No differences were found between the subject groups in the HGP measured during the period of study.

Hyperinsulinaemic hyperglycaemic clamp. A subset of eight donor subjects and eight control subjects completed both the euglycaemic and hyperglycaemic hyperinsulinaemic clamp studies. The serum specific activities achieved during this investigation are shown in Table 3. On the second study day both donor subjects and control subjects were clamped at approximately $11.1 \mathrm{mmol} / \mathrm{l}$ during the sequential infusions of insulin on day 2 (Fig. 3). The insulin levels measured were the same in each group and not different from the insulin values achieved during the euglycaemic clamp study (Fig. 3). Both donor subjects and control subjects demonstrated increasing $R_{d}$ values as the insulin levels were elevated during day 2 (Fig.3). No differences were found in the rates of $\mathbf{R}_{d}$ between the subject groups during the hyperglycaemic clamp study.
E. Seaquist et al.: Glucose turnover after hemipancreatectomy

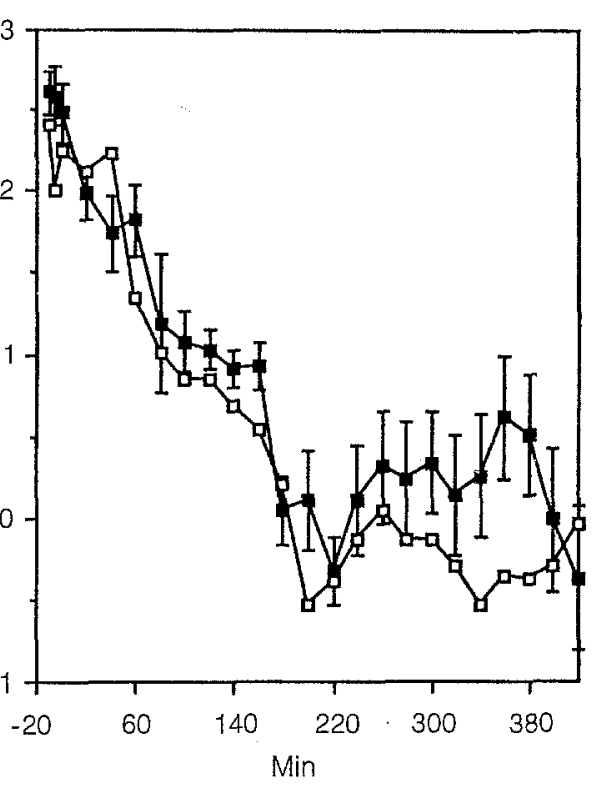

Glucose-mediated glucose uptake. Glucose-mediated glucose uptake $(\Delta \mathrm{Rd})$, which is equal to the difference between the $R_{d}$ values measured during the euglycaemic and hyperglycaemic clamps performed at the same insulin infusion rate, was found to be the same in both donor and control groups. The $\Delta \mathrm{Rd}$ value at the infusion rate of $1.0 \mathrm{mU} \cdot \mathrm{kg}^{-1} \cdot \mathrm{min}^{-1}$ was $3.82 \pm 1.01 \mathrm{mg} \cdot \mathrm{kg}^{-1} \cdot \mathrm{min}^{-1}$ in donor subjects and $6.09 \pm 1.24 \mathrm{mg} \cdot \mathrm{kg}^{-1} \cdot \mathrm{min}^{-1}$ in control subjects $(p=\mathrm{NS})$.

Minimal model. The index of insulin sensitivity $\left(\mathrm{S}_{\mathrm{I}}\right)$ measured in five donor subjects was $11.1 \pm 6.0 \cdot 10^{-5}$ $\mathrm{min}^{-1} \cdot \mathrm{pmol} / \mathrm{l}^{-1}$. This was not different from the $S_{I}$ measured in five matched control subjects $\left(10.5 \pm 3.8 \cdot 10^{-5} \mathrm{~min}^{-1} \cdot \mathrm{pmol} / \mathrm{l}^{-1}, p=\mathrm{NS}\right)$. Similarly, no increase in glucose effectiveness $\left(\mathrm{S}_{\mathrm{G}}\right)$ was found in the donor subjects compared to control subjects $\left(2.1 \pm 0.6 \cdot 10^{-2} \mathrm{~min}^{-1}\right.$ vs $5.1 \pm 0.3 \cdot 10^{-2} \mathrm{~min}^{-1}$; donor subjects vs control subjects, $p=\mathrm{NS}$ ).

\section{Discussion}

Hemipancreatectomy in healthy human donor subjects causes a decrease in glucose- and arginine-induced insulin secretion and diminished glucose potentiation of arginine-induced insulin secretion [8]. Despite these abnormalities, most donor subjects maintain normoglycaemia during daily living [7] and have serum glucose responses to prolonged infusions of glucose that are identical to those of control subjects [8]. This study was designed to determine whether normoglycaemia is maintained in donor subjects through an increase in rates of insulin- or glucose-mediated glucose uptake. We hypothesized that such an increase could be a mechanism through which healthy hemipancreatectomized humans com- 

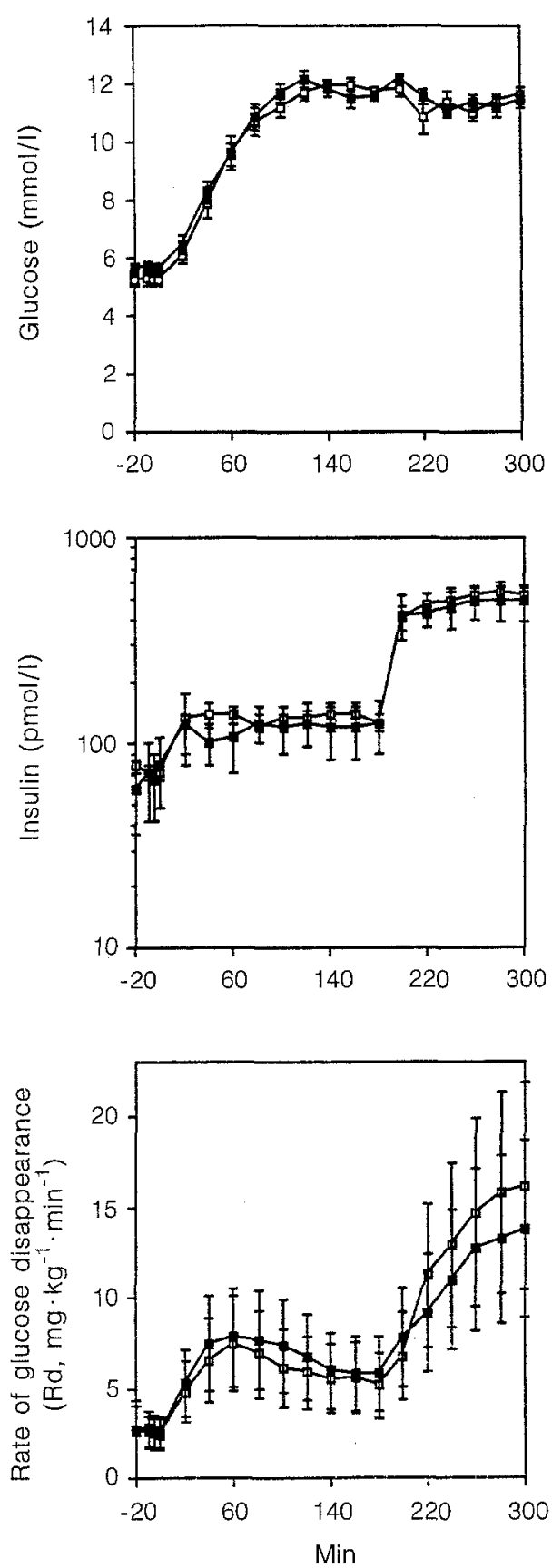

Fig. 3. Glucose, insulin and glucose disappearance rates during hyperglycaemic hyperinsulinaemic clamps in hemipancreatectomized human donor subjects and control subjects. Eight donor subjects ( $\boldsymbol{\square})$ and 8 control subjects $(\square)$ underwent hyperglycaemic clamps at insulin infusion rates of $0.25 \mathrm{mU} \cdot \mathrm{kg}^{-1}$ . $\min ^{-1}$ for $180 \mathrm{~min}$ followed by $1.0 \mathrm{mU} \cdot \mathrm{kg}^{-1} \cdot \mathrm{min}^{-1}$ for $120 \mathrm{~min}$ on two separate days. Somatostatin $\left(0.16 \mu \mathrm{g} \cdot \mathrm{kg}^{-1}\right.$ . $\mathrm{min}^{-1}$ ) was infused from 0 to $300 \mathrm{~min}$. Serum concentrations of glucose (top panel), insulin (middle panel), and rates of glucose disappearance were not different between hemipancreatectomized donor subjects and control subjects

pensate for diminished insulin secretion following reduction of beta-cell mass. From our investigation we have found that healthy hemipancreatectomized human donor subjects appear to maintain normal rates of glucose turnover during a hyperinsulinaemic euglycaemic clamp, a process that is largely determined by insulin-mediated glucose uptake, and have normal rates of glucose-mediated glucose uptake. Donor subjects and control subjects were also found to have similar values for insulin sensitivity and glucose effectiveness using the minimal model protocol. These findings demonstrate that these methods do not detect the compensatory increases in insulin- or glucose-mediated hepatic or peripheral glucose disposal that we hypothesized to exist in human donor subjects. Therefore, the question remains: how do healthy hemipancreatectomized human donor subjects maintain normoglycaemia after a reduction of the pancreatic mass by half?

One potential mechanism underlying our findings can be understood by recognizing that human donor subjects lose not only half of their beta-cell mass following hemipancreatectomy, but half of their alphacell mass as well. Unlike dogs or rodents where alpha cells are concentrated in the tail of the pancreas and beta cells are concentrated in the head [17] humans have an equal distribution of both cell types throughout their pancreas [18]. Therefore, surgical excision of portions of the pancreas does not alter the relative amounts in glucagon and insulin secretory cells remaining in the organ remnant. If both hormones are secreted in the same appropriate physiologic balance after hemipancreatectomy as before, normal glucose tolerance and normal rates of glucose turnover may be maintained. We have previously demonstrated that arginine-induced glucagon secretion is markedly impaired in human donor subjects to a degree similar to that with which arginine-induced insulin secretion is altered [8]. It is thus possible that the maintenance of balanced glucagon and insulin secretion following organ donation allows for the normal rates of glucose turnover observed in healthy hemipancreatectomized subjects. Support for our thesis can be found in the report by Magnusson and colleagues [19] examining the effect of an $85 \%$ pancreatectomy on insulin sensitivity in individuals suffering from carcinoma of the pancreatic head. These investigators found similar responses to bolus infusions of insulin before and after surgery and concluded that insulin action is not altered after a reduction in beta-cell mass, perhaps because of an equal decrease in glucagon and insulin secretion. However, other investigators have suggested that it is not the relationship between glucagon and insulin values that is important in the regulation of glucose turnover, but the absolute level of insulin that determines the rates of HGP and glucose utilization [20]. The applicability of these studies to our own are uncertain since they were performed in dogs under short-term experimental conditions, rather than in humans with prolonged relative hypoinsulinaemia and hypoglucagonaemia. Perhaps in the situation we studied the ratio of insu- 
lin to glucagon assumes a more important role in the regulation of glucose metabolism than in the canine model studied previously. Indeed, investigations in totally pancreatectomized humans suggest that absolute glucagon levels may be more important in the overall regulation of glucose turnover than was once thought [21].

Another possible explanation for our findings is that the techniques used, while representing the standards with which to measure insulin action, are insufficiently precise to measure small but physiologically relevant differences in glucose turnover rates between our two subject groups. As recently suggested by Kahn and colleagues [22], a hyperbolic relationship may exist between measures of beta-cell function and insulin sensitivity in a healthy population such that changes in insulin secretion may have relatively small effects on insulin sensitivity if the $S_{I}$ exceeds the median for a normal population [22]. Based on this model, healthy normoglycaemic individuals of average body mass, such as the donor subjects prior to hemipancreatectomy, would be expected to have a sufficiently high $S_{\text {I }}$ to experience little change in response to even significant changes in beta-cell function. Therefore, a more precise method may be necessary to determine if donor subjects experience a difference in glucose turnover after hemipancreatectomy. Alternatively, examination of insulin secretion and glucose disposal under more physiologic circumstances than the hyperinsulinaemic clamp or the minimal model protocol, such as ingestion of a radioisotopically-labelled meal [23], may be required to more sensitively address whether donor subjects compensate for diminished beta-cell function by increasing insulin- or glucosemediated glucose uptake following hemipancreatectomy.

In conclusion, hemipancreatectomy in healthy human donor subjects does not appear to alter insulinmediated or glucose-mediated glucose uptake as determined by hyperinsulinaemic clamp and minimal model methodologies. Thus, our data indicate that donor subjects can maintain normal glucose tolerance without making compensatory changes in HGP or peripheral glucose uptake despite a markedly diminished insulin secretory response to glucose and arginine. The mechanisms through which hemipancreatectomized humans maintain euglycaemia remain uncertain, but may involve maintenance of normal glucagon to insulin ratios or small but physiologically relevant changes in glucose metabolism which are undetectable by the methods employed in our investigation.

Acknowledgements. The authors gratefully acknowledge the invaluable help of Ms. K. Adams, RN, and the staff of the Clinical Research Center at the University of Minnesota; the expert technical assistance of Ms. L. Pohlman, Ms. E. Oseid, Mr. M. Greene, and Ms. M. McDonald, and the excellent secretari- al support of Ms. K. Steinmeyer, Dr. M. Segall generously assisted with the Minimal Model calculations. This work was supported by grants KO8 DK 01920 (E.R.S.) and RO1 DK 39994 (R.P.R.) from National Institutes of Health.

\section{References}

1. Sun AM, Coddling JA, Haist RE (1974) A study of glucose tolerance and insulin response in partially depancreatized dogs. Diabetes 23: 424-432

2. Bonner-Weir S, Trent DF, Weir GC (1983) Partial pancreatectomy in the rat and subsequent defect in glucose-induces insulin release. J Clin Invest 71: 1544-1553

3. Leahy JL, Bonner-Weir S, Weir GC (1984) Abnormal glucose regulation of insulin secretion in models of reduced B-cell mass. Diabetes 33: 667-673

4. Rossetti L, Shulman GI, Zawalich W, DeFronzo RA (1987) Effect of chronic hyperglycemia on in vivo insulin secretion in partially pancreatectomized rats. J Clin Invest 80: 10371044

5. Leahy JL, Bonner-Weir S, Weir GC (1988) Minimal chronic hyperglycemia is a critical determinant of impaired insulin secretion after an incomplete pancreatectomy. J Clin Invest 81: 1407-1414

6. Ward WK, Wallum BJ, Beard JC, Taborsky GJ, Porte D (1988) Reduction of glycemic potentiation. Sensitive indicator of $\beta$-cell loss in partially pancreatectomized dogs. Diabetes 37: 723-729

7. Kendall DM, Sutherland DER, Najarian JS, Goetz FC, Robertson RP (1990) Effects of hemipancreatectomy on insulin secretion and glucose tolerance in healthy humans. $\mathrm{N}$ Engl J Med 322: 898-903

8. Seaquist ER, Robertson RP (1992) Effects of hemipancreatectomy on pancreatic alpha and beta cell function in healthy human donors. J Clin Invest 89: 1761-1766

9. Gottesman I, Mandarino L, Gerich J (1983) Estimation and kinetic analysis of insulin-independent glucose uptake in human subjects. Am J Physiol 244: E632-E635

10. Bergman RN, Prager R, Volund A, Olefsky JM (1987) Equivalence of the insulin sensitivity index in man derived by the minimal model method and the euglycemic glucose clamp. J Clin Invest 79: 790-800

11. Morgan CR, Lazarow A (1963) Immunoassay of insulin: two antibody system. Diabetes $12: 115-126$

12. Harris V, Falooma GR, Unger RH (1979) Glucagon. In: BM Jaffe, HR Behrman (eds) Methods of hormone radioimmunoassay. Academic Press, New York, p. 643

13. Somogyi M (1945) Determination of blood sugar. J Biol Chem 160: 69-73

14. Finegood DT, Bergman RN, Vranic M (1987) Estimation of endogenous glucose production during hyperinsulinemic-euglycemic glucose clamps. Comparison of unlabelled and labelled exogenous glucose infusates. Diabetes 36 : 914-924

15. Steele R, Wall JS, DeBodo RC, Altszuler N (1956) Measurement of size and turnover rate of body glucose pool by the isotope dilution method. Am J Physiol 187: 15-24

16. DeBodo RC, Steele R, Altszuler N, Dunn A, Bishop JS (1963) On the hormonal regulation of carbohydrate metabolism; studies with $C^{14}$ glucose. Rec Prog Horm Res 19: 445-488

17. Gotoh M, Monden M, Okamura J, Mori T, Shima K (1989) Insulin and glucagon secretion after pancreatectomies. Correlation of secretion and hormonal contents of remaining pancreas. Diabetes 38: 861-867 
18. Gersell DJ, Gingerich RL, Greider MH (1979) Regional distribution and concentration of pancreatic polypeptide in the human and canine pancreas. Diabetes 28: 11-15

19. Magnusson J, Bengmark S, Tranberg K-G (1990) Reduced insulin secretion by subtotal pancreatectomy: preservation of insulin sensitivity and glucose tolerance in postoperative patients. Scand J Gastroenterol 25: 669-675

20. Steiner KE, Williams PE, Lacy WW, Cherrington AD (1990) Effects of insulin on glucagon-stimulated glucose production in the conscious dog. Metabolism 39: 1325-1333
21. Bajorunas DR, Dresler CM, Horowitz GD et al. (1986) Basal glucagon replacement in chronic glucagon deficiency increases insulin resistance. Diabetes 35: 556-562

22. Kahn SE, Prigeon RL, McCulloch DK et al. (1993) Quantification of the relationship between insulin sensitivity and $\beta$-cell function in human subjects. Diabetes 42 : $1663-$ 1672

23. Katz H, Homan M, Velosa J, Robertson P, Rizza R (1991) Effects of pancreas transplantation on postprandial glucose metabolism. N Engl J Med 325: 1278-1283 